\title{
Native Valve Endocarditis due to Veillonella Species: A Case Report and Review of the Literature
}

\author{
Lakshmi Saladi, Cosmina Zeana, and Manisha Singh \\ Department of Medicine, Bronx Lebanon Hospital Center, Bronx, NY 10457, USA \\ Correspondence should be addressed to Manisha Singh; msingh1@bronxleb.org \\ Received 23 January 2017; Revised 5 April 2017; Accepted 20 April 2017; Published 14 May 2017 \\ Academic Editor: Jean-François Faucher
}

Copyright (C) 2017 Lakshmi Saladi et al. This is an open access article distributed under the Creative Commons Attribution License, which permits unrestricted use, distribution, and reproduction in any medium, provided the original work is properly cited.

\begin{abstract}
Veillonella species are fastidious bacteria that have been isolated from skin, dental, and respiratory tract infections and rarely have been implicated in serious infections like meningitis, endocarditis, and osteomyelitis. A 76-year-old woman presented to our hospital with fever, vomiting, and generalized weakness for 3 days. A transthoracic echocardiogram showed a mobile structure on anterior mitral valve leaflet measuring $0.9 \mathrm{~cm}$ suggestive of vegetation. Empiric therapy with vancomycin and piperacillintazobactam was started with clinical resolution of her symptoms. On day 6, the blood culture drawn at admission grew Veillonella species. A transesophageal echocardiogram confirmed a $1.2 \times 0.4 \mathrm{~cm}$ echo dense structure attached to the left ventricular side of the anterior mitral leaflet. The patient was discharged home after 10 days of inpatient antibiotic therapy and completed 4 weeks of IV ceftriaxone at home without any adverse events. She was reevaluated in the clinic after completion of treatment and repeat blood cultures remained negative. We report the first case of successful treatment of endocarditis due to Veillonella species with once daily ceftriaxone.
\end{abstract}

\section{Introduction}

Veillonella species are anaerobic, Gram-negative cocci that are part of the normal mouth, gastrointestinal, and urogenital flora in humans. Veillonella species have been isolated from skin, dental, and respiratory tract infections where they are often part of a mixed flora. Rarely, Veillonella can cause serious infections like meningitis, endocarditis, and osteomyelitis.

\section{Case Summary}

A 76-year-old woman with medical history of diabetes mellitus, hypertension, chronic hepatitis $\mathrm{C}$ with cirrhosis, esophageal variceal bleeding, and stage 4 chronic kidney disease presented to the hospital with fever, vomiting, and generalized weakness for three days.

On physical examination, she was in no apparent distress, a grade $3 / 6$ systolic murmur was audible in the right 2nd intercostal space, lungs were clear to auscultation with equal breath sounds bilaterally, and abdomen was soft and nontender, with normal bowel sounds. She had no focal neurological deficits. Grade 2+ pitting pedal edema was present bilaterally and skin was intact without any rash. The remainder of the examination was unremarkable.

A complete blood count revealed anemia with hemoglobin of $10 \mathrm{~g} / \mathrm{dL}$ and a white blood cell count of 7500 cell/microliter ( $81 \%$ neutrophils, $6 \%$ lymphocytes, and $12 \%$ monocytes). Platelet count was 68000 and international normalized ratio (INR) was 1.1. Patient had abnormal renal function with serum creatinine of 2.5. Urinalysis was significant for $150 \mathrm{mg} / \mathrm{dL}$ of protein, moderate blood, large leucocyte esterase, and negative nitrite. A transthoracic echocardiogram showed a mobile $0.9 \mathrm{~cm}$ structure on the anterior mitral valve leaflet. Empiric therapy with vancomycin and piperacillin-tazobactam was started after 2 sets of blood cultures were obtained. On day 2 of hospitalization, growth of Gram-positive cocci was reported in 1 out of the 2 blood cultures drawn on admission. On day 6, the organism was identified as Veillonella species. The patient complained of dysuria during the admission and was diagnosed with urinary tract infection caused by extended spectrum beta lactamase producing Escherichia coli. Therefore piperacillin-tazobactam was changed to 
TABLE 1: Cases of endocarditis due to Veillonella species.

\begin{tabular}{|c|c|c|c|c|c|c|c|}
\hline & Age/gender & $\begin{array}{c}\text { Valve } \\
\text { involved }\end{array}$ & $\begin{array}{l}\text { Type of } \\
\text { valve }\end{array}$ & Organism & Antibiotics & Surgery & $\begin{array}{c}\text { Microbiologic } \\
\text { and clinical } \\
\text { cure }\end{array}$ \\
\hline (1) $[6]$ & $35 / \mathrm{M}$ & Mitral & Native & $\begin{array}{l}\text { Veillonella } \\
\text { alcalescens }\end{array}$ & $\begin{array}{c}\text { Penicillin G, } \\
\text { sulfadiazine, } \\
\text { heparin, and } \\
\text { para- } \\
\text { aminohippurate } \\
\text { for } 18 \text { months }\end{array}$ & No & Yes \\
\hline (2) $[8]$ & $60 / \mathrm{M}$ & Aortic & Native & $\begin{array}{l}\text { Veillonella } \\
\text { alcalescens }\end{array}$ & $\begin{array}{l}\text { Cephapirin and } \\
\text { gentamicin ( } \\
\text { weeks) and oral } \\
\text { penicillin V for } \\
6 \text { months }\end{array}$ & Yes & Yes \\
\hline (3) $[5]$ & $57 / \mathrm{F}$ & Mitral & Prosthetic & $\begin{array}{l}\text { Veillonella } \\
\text { dispar }\end{array}$ & $\begin{array}{c}\text { Ampicillin } 2 \\
\text { weeks and } \\
\text { clindamycin and } \\
\text { metronidazole } 2 \\
\text { weeks }\end{array}$ & Yes & Yes \\
\hline (4) $[12]$ & NA & $\begin{array}{l}\text { Mitral, } \\
\text { aortic, } \\
\text { and } \\
\text { tricuspid }\end{array}$ & NA & $\begin{array}{c}\text { Veillonella } \\
\text { parvula }\end{array}$ & Clindamycin & No & Yes \\
\hline (5) $[13]$ & $51 / \mathrm{M}$ & Mitral & Prosthetic & $\begin{array}{l}\text { Veillonella } \\
\text { alcalescens }\end{array}$ & $\begin{array}{c}\text { Penicillin G for } \\
6 \text { weeks }\end{array}$ & Yes & Yes \\
\hline (6) $[4]$ & $56 / \mathrm{M}$ & Mitral & Prosthetic & $\begin{array}{c}\text { Veillonella } \\
\text { dispar }\end{array}$ & $\begin{array}{c}\text { Penicillin G for } \\
6 \text { weeks }\end{array}$ & No & Yes \\
\hline (7) [7] & $49 / \mathrm{M}$ & Mitral & Prosthetic & $\begin{array}{l}\text { Veillonella } \\
\text { parvula }\end{array}$ & $\begin{array}{l}\text { Metronidazole } \\
\text { for } 6 \text { weeks }\end{array}$ & Yes & Yes \\
\hline (8) [9] & $75 / \mathrm{F}$ & $\begin{array}{l}\text { Mitral } \\
\text { and } \\
\text { aortic }\end{array}$ & Native & $\begin{array}{l}\text { Veillonella } \\
\text { montpel- } \\
\text { lierensis }\end{array}$ & $\begin{array}{l}\text { Amoxicillin (6 } \\
\text { weeks) and } \\
\text { gentamicin (3 } \\
\text { weeks) }\end{array}$ & No & $\begin{array}{l}\text { Information } \\
\text { not available }\end{array}$ \\
\hline $\begin{array}{l}\text { (9) Present } \\
\text { work }\end{array}$ & $76 / \mathrm{M}$ & Mitral & Native & Veillonella & $\begin{array}{c}\text { Ceftriaxone for } \\
6 \text { weeks }\end{array}$ & No & Yes \\
\hline
\end{tabular}

M: male; F: female; NA: not available.

meropenem to complete 3 days of therapy. A transesophageal echocardiogram confirmed a $1.2 \times 0.4 \mathrm{~cm}$ echo dense structure attached to the LV side of the anterior mitral leaflet. The isolate was reported sensitive to penicillin and cephalosporins and resistant to metronidazole. At this time, vancomycin was discontinued and meropenem was changed to ceftriaxone. Repeat blood cultures remained negative. The hospital course was complicated by diarrhea due to Clostridium difficile which was treated with metronidazole with clinical improvement.

Patient was discharged with a peripherally inserted central catheter after 10 days of inpatient therapy and she completed 4 weeks of IV ceftriaxone at home without any adverse events. She was reevaluated in the clinic after completion of treatment and repeat blood cultures were negative. Follow-up at one year with repeat echocardiogram showed resolution of the vegetation.

\section{Discussion}

Veillonella species are small, spherical, Gram-negative cocci that grow under anaerobic conditions on the usual media.
They have limited fermentative properties and appear to be harmless saprophytes; though occasionally they may invade the blood stream leading to serious infections like meningitis, endocarditis, and osteomyelitis. 13 species have been identified so far: V. parvula, V. dispar, V. atypica, $V$. caviae, $V$. rodentium, $V$. ratti, $V$. criceti, V. montpellierensis, $V$. denticariosi, $V$. tobetsuensis, V. magna, V. rogosae, and $V$. seminalis [1-3].

There have been 8 prior documented cases of endocarditis with Veillonella species as the sole isolate (Table 1). Of these, 4 cases involved prosthetic valves and 4 cases affected native valves.

Interestingly, blood cultures were positive in only 3 of the 8 reported cases [4-6]. In 2 cases the diagnosis was made with growth of the bacteria from valve tissue $[7,8]$ and in one case the organism was identified with 16sRNA analysis [9]. In our case, 1 out of 2 blood cultures drawn prior to administration of antibiotics were reported positive. If Duke's criteria are strictly applied, this would be categorized as "possible infective endocarditis." 
The optimal antimicrobial treatment of endocarditis caused by Veillonella sp. is not standardized. Among the reported cases, antibiotics used include penicillin, ampicillin, first-generation cephalosporin, metronidazole, clindamycin, or aminoglycosides either as monotherapy or in combination $[4-8,10-13]$. Penicillin was initially used as the antibiotic of choice $[9,10]$. A later study reported high level resistance to penicillin $\mathrm{G}$ among oral isolates of Veillonella sp. that retained susceptibility to amoxicillin-clavulanate [14]. Among the 8 reported cases of endocarditis, susceptibility data are available in only 3 of the isolates $[4,6,7]$. Reduced penicillin susceptibility was reported in 2 of those [6,7]. Metronidazole alone has been used in one case of endocarditis caused by Veillonella sp. with reduced penicillin susceptibility [7]; only one reported case was treated with a first-generation cephalosporin in combination with gentamicin followed by oral penicillin treatment [8].

In addition to antibiotic therapy, 3 out of the 4 patients with prosthetic valve endocarditis required surgical intervention $[4,5]$.

The isolate in our patient was susceptible to penicillin (MIC $<0.06$ ), cephalosporins ( $\mathrm{MIC}<2$ ), ampicillinsulbactam $(\mathrm{MIC}<1)$, piperacillin, clindamycin, and tetracycline and was resistant to metronidazole. The patient was successfully treated with ceftriaxone alone for 4 weeks.

\section{Conclusion}

The importance of Veillonella species as a cause of serious infections including endocarditis has been increasingly recognized. The diagnosis may be difficult due to fastidious nature of the bacterium and there are limited clinical data in the available literature for guiding treatment in these cases. We report the first case of successful treatment of endocarditis due to Veillonella species with once daily ceftriaxone.

\section{Conflicts of Interest}

The authors have no conflicts of interest to report.

\section{References}

[1] M. Rogosa, “The genus Veillonella," Journal of Bacteriology, vol. 87, no. 1, pp. 162-170, 1964.

[2] E. Igarashi, A. Kamaguchi, M. Fujita, H. Miyakawa, and F. Nakazawa, "Identification of oral species of the genus Veillonella by polymerase chain reaction," Oral Microbiology and Immunology, vol. 24, no. 4, pp. 310-313, 2009.

[3] I. Mashima and F. Nakazawa, "Interaction between Streptococcus spp. and Veillonella tobetsuensis in the early stages of oral biofilm formation," Journal of Bacteriology, vol. 197, no. 13, pp. 2104-2111, 2015.

[4] S. Houston, D. Taylor, and R. Rennie, "Prosthetic valve endocarditis due to Veillonella dispar: successful medical treatment following penicillin desensitization," Clinical Infectious Diseases, vol. 24, no. 5, pp. 1013-1014, 1997.

[5] A. C. Loughrey and E. W. Chew, "Endocarditis caused by Veillonella dispar," Journal of Infection, vol. 21, no. 3, pp. 319321, 1990.
[6] L. Loewe, P. Rosenblatt, and E. Alture-Werber, "A refractory case of subacute bacterial endocarditis due to veillonella gazogenes clinically arrested by a combination of penicillin, sodium paraaminohippurate, and heparin," American Heart Journal, vol. 32, no. 3, pp. 327-338, 1946.

[7] T. W. Boo, B. Cryan, A. O’Donnell, and G. Fahy, "Prosthetic valve endocarditis caused by Veillonella parvula," The Journal of Infection, vol. 50, no. 1, pp. 81-83, 2005.

[8] W. L. Greaves and A. B. Kaiser, "Endocarditis due to veillonella alcalescens," Southern Medical Journal, vol. 77, no. 9, pp. 12111212, 1984.

[9] C. Rovery, A. Etienne, C. Foucault, P. Berger, and P. Brouqui, "Veillonella montpellierensis endocarditis," Emerging Infectious Diseases, vol. 11, no. 7, pp. 1112-1114, 2005.

[10] M. A. Pérez-Jacoiste Asín, M. Fernández-Ruiz, I. SerranoNavarro, S. Prieto-Rodriguez, and J. M. Aguado, "Polymicrobial endocarditis involving Veillonella parvula in an intravenous drug user: case report and literature review of Veillonella endocarditis," Infection, vol. 41, no. 2, pp. 591-594, 2013.

[11] S. Oh, P. R. Havlen, and N. Hussain, "A case of polymicrobial endocarditis due to anaerobic organisms in an injection drug user," Journal of General Internal Medicine, vol. 20, no. 10, pp. C1-C2, 2005.

[12] P. Sanchez-Molini, L. I. Becerra, and L. R. Diaz, "Infective endocarditis and pulmonary abscess in an intravenous drug addict caused by Veillonella parvula," Revista Clinica Espanola, vol. 188, pp. 382-383, 1991.

[13] C. Zussa, P. Ius, F. Cesari et al., "Fortuitous detection of prosthetic valve endocarditis caused by an uncommon etiologic agent," Journal of Thoracic and Cardiovascular Surgery, vol. 107, no. 4, pp. 1167-1168, 1994.

[14] S. Nyfors, E. Könönen, A. Bryk, R. Syrjänen, and H. JousimiesSomer, "Age-related frequency of penicillin resistance of oral Veillonella," Diagnostic Microbiology and Infectious Disease, vol. 46, no. 4, pp. 279-283, 2003. 


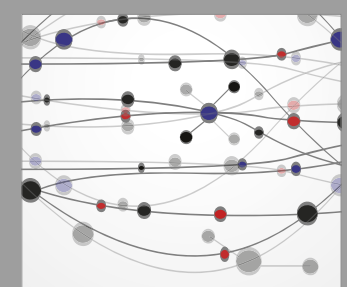

The Scientific World Journal
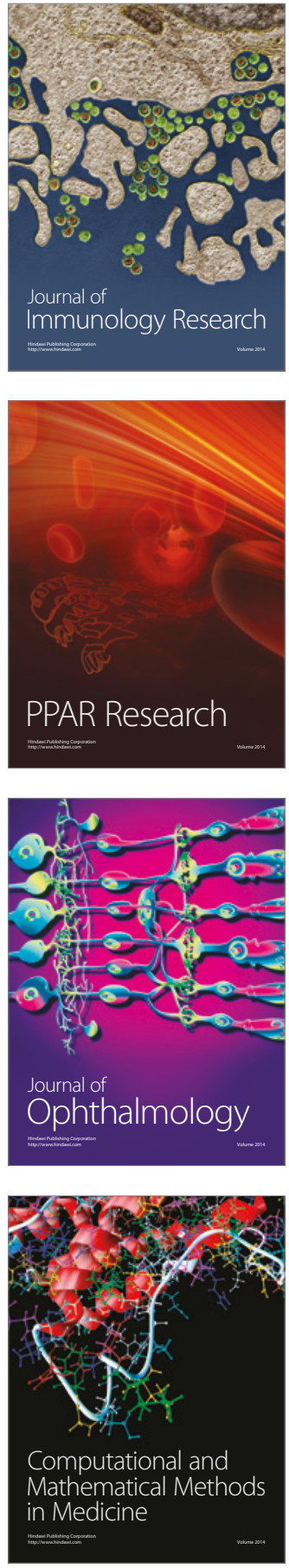

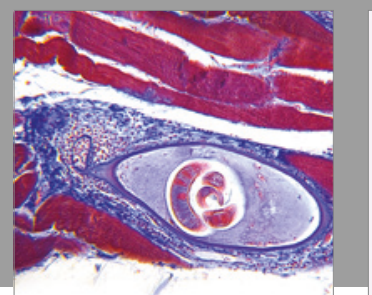

Gastroenterology Research and Practice
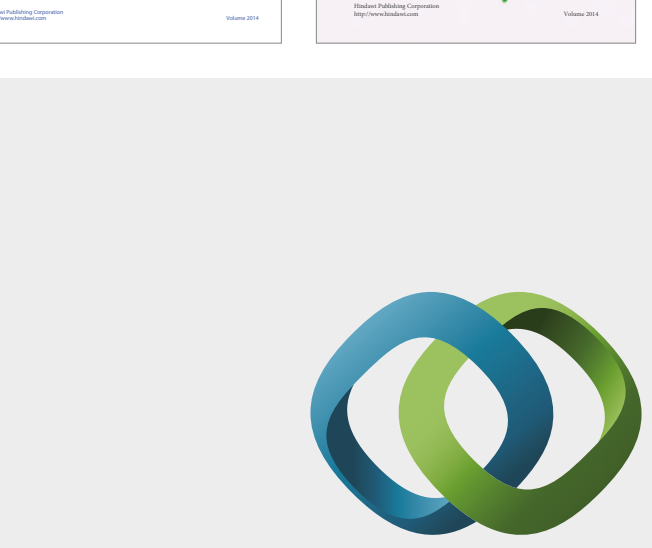

\section{Hindawi}

Submit your manuscripts at

https://www.hindawi.com
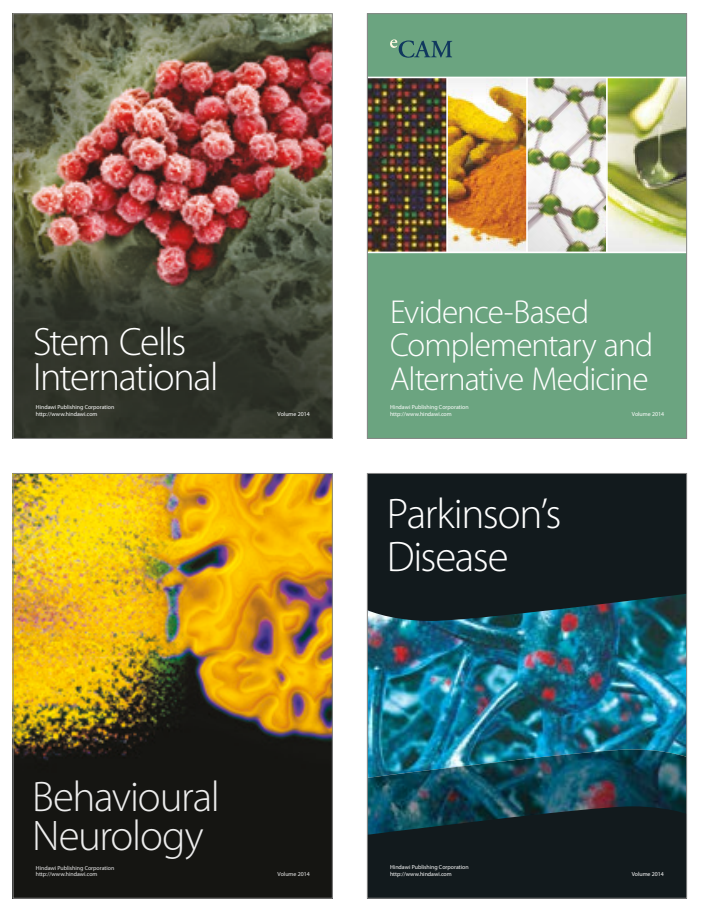
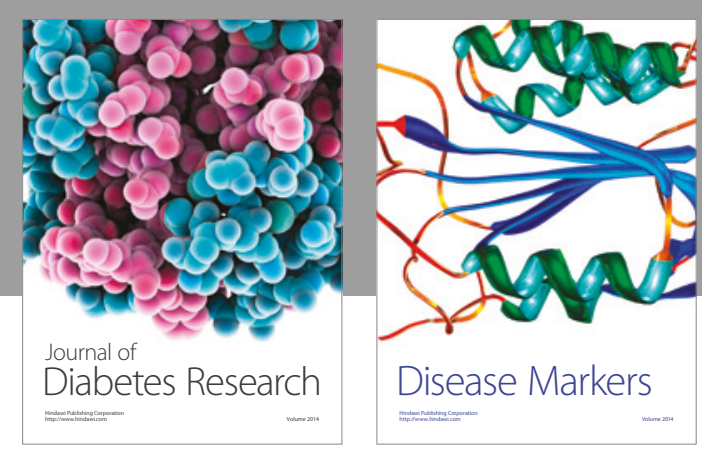

Disease Markers
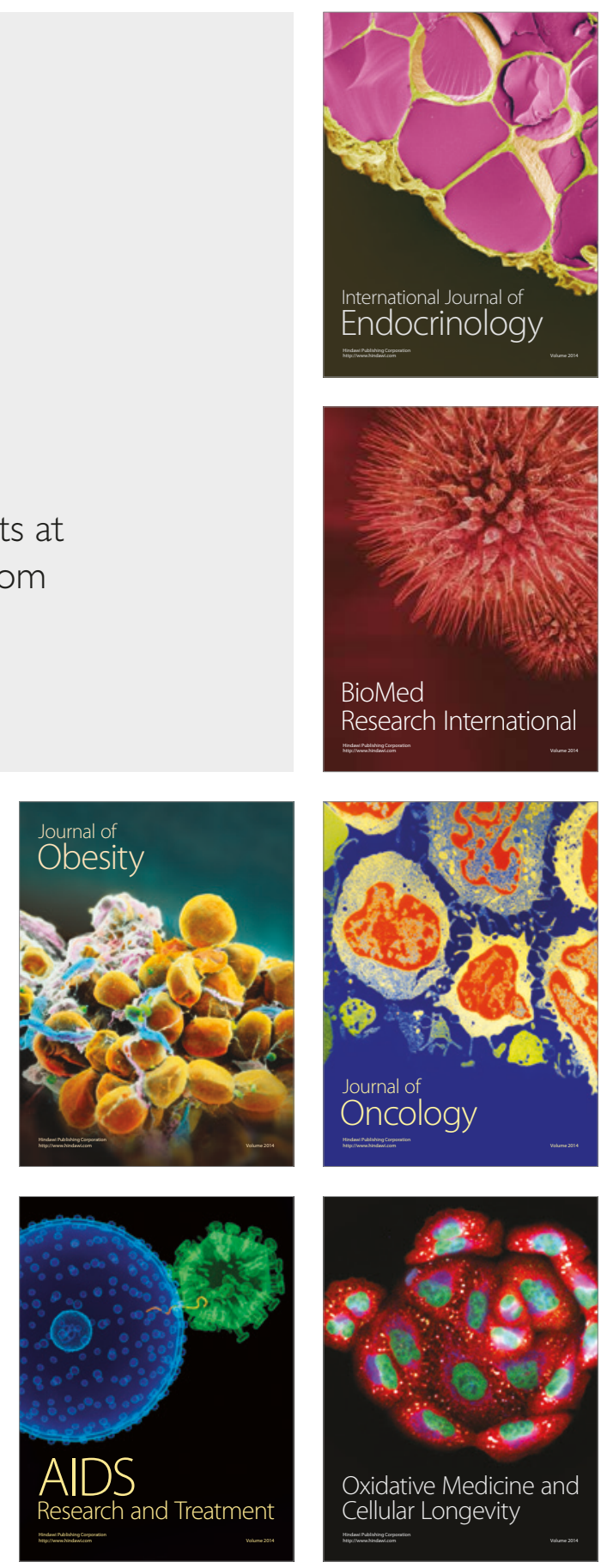